\title{
Observation of Violet-Light Emission Band for Thulium-Doped Tantalum-Oxide Films Produced by Co-Sputtering
}

\author{
Kenta Miura*, Tetsuhito Suzuki, Osamu Hanaizumi \\ Graduate School of Science and Technology, Gunma University, Kiryu, Japan \\ Email: ${ }^{*}$ mkenta@gunma-u.ac.jp
}

Received 16 June 2015; accepted 11 July 2015; published 14 July 2015

Copyright @ 2015 by authors and Scientific Research Publishing Inc.

This work is licensed under the Creative Commons Attribution-NonCommercial International License (CC BY-NC).

http://creativecommons.org/licenses/by-nc/4.0/

(c) (1) (9) 0 pen Access

\section{Abstract}

We prepared thulium-doped tantalum (V) oxide $\left(\mathrm{Ta}_{2} \mathrm{O}_{5}: \mathrm{Tm}\right)$ thin films using co-sputtering of two $\mathrm{Tm}_{2} \mathrm{O}_{3}$ pellets and $\mathrm{a} \mathrm{Ta}_{2} \mathrm{O}_{5}$ disc, and we observed photoluminescence (PL) peaks not only around a wavelength of $800 \mathrm{~nm}$ due to the ${ }^{3} \mathrm{H}_{4} \rightarrow{ }^{3} \mathrm{H}_{6}$ transition of $\mathrm{Tm}^{3+}$ but also around a wavelength of 400 $\mathrm{nm}$ (violet) from the films after annealing for the first time. Comparatively narrow PL peaks around the wavelength of $400 \mathrm{~nm}$ were observed from the films annealed at $800^{\circ} \mathrm{C}$ and $900^{\circ} \mathrm{C}$ for $20 \mathrm{~min}$. The peak intensity from the film annealed at $900^{\circ} \mathrm{C}$ was approximately four-times stronger than that from the film annealed at $800^{\circ} \mathrm{C}$. The origin of the $400-\mathrm{nm}$ peaks seems to be the same as our non-doped $\mathrm{Ta}_{2} \mathrm{O}_{5}$ thin films deposited using radio-frequency sputtering because we observe PL peaks around $400-430 \mathrm{~nm}$ from the $\mathrm{Ta}_{2} \mathrm{O}_{5}$ films. Such a $\mathrm{Ta}_{2} \mathrm{O}_{5}: \mathrm{Tm}$ co-sputtered thin film seems to be used as a multi-functional coating film having both anti-reflection and down-conversion effects for realizing a high-efficiency silicon solar cell.

\section{Keywords}

Tantalum Oxide, Thulium, Co-Sputtering, Violet-Light Emission Band

\section{Introduction}

Tantalum (V) oxide $\left(\mathrm{Ta}_{2} \mathrm{O}_{5}\right)$ is a high-refractive-index material used in passive optical elements such as $\mathrm{Ta}_{2} \mathrm{O}_{5} /$ $\mathrm{SiO}_{2}$ multilayered wavelength filters for dense wavelength-division multiplexing. It has also been used as a high-index material of $\mathrm{Ta}_{2} \mathrm{O}_{5} / \mathrm{SiO}_{2}$ multilayered photonic-crystal elements for the visible to near-infrared range

*Corresponding author.

How to cite this paper: Miura, K., Suzuki, T. and Hanaizumi, O. (2015) Observation of Violet-Light Emission Band for Thulium-Doped Tantalum-Oxide Films Produced by Co-Sputtering. Materials Sciences and Applications, 6, 656-660. 
fabricated using the autocloning method based on radio-frequency (RF) bias sputtering [1] [2], and it can additionally be used as an anti-reflection coating material for silicon solar cells [3]. However, $\mathrm{Ta}_{2} \mathrm{O}_{5}$ has recently attracted much attention as an active optical material, since broad red photoluminescence (PL) spectra at wavelengths of 600 to $650 \mathrm{~nm}$ are observed from thermal-oxidized amorphous $\mathrm{Ta}_{2} \mathrm{O}_{5}$ thin films [4]. In our previous work, we demonstrated blue PL from $\mathrm{Ta}_{2} \mathrm{O}_{5}$ thin films deposited by RF magnetron sputtering [5].

In addition, many studies on rare-earth-doped $\mathrm{Ta}_{2} \mathrm{O}_{5}$ have been conducted because $\mathrm{Ta}_{2} \mathrm{O}_{5}$ is a potential host material for new phosphors or efficient down-conversion luminescent materials due to its lower phonon energy from 100 to $450 \mathrm{~cm}^{-1}$ than other popular oxides such as $\mathrm{SiO}_{2}$ [6]. We have reported on various rare-earth ( $\mathrm{Er}$, $\mathrm{Eu}$, $\mathrm{Y}, \mathrm{Yb}$, and $\mathrm{Ce})$ doping into $\mathrm{Ta}_{2} \mathrm{O}_{5}$ thin films using simply co-sputtering of rare-earth oxide $\left(\mathrm{Er}_{2} \mathrm{O}_{3}, \mathrm{Eu}_{2} \mathrm{O}_{3}, \mathrm{Y}_{2} \mathrm{O}_{3}\right.$, $\mathrm{Yb}_{2} \mathrm{O}_{3}$, and $\mathrm{CeO}_{2}$ ) pellets and a $\mathrm{Ta}_{2} \mathrm{O}_{5}$ disc, and we have observed various $\mathrm{PL}$ from our rare-earth-doped $\mathrm{Ta}_{2} \mathrm{O}_{5}$ thin films [7]-[17]. We also fabricated thulium-doped $\mathrm{Ta}_{2} \mathrm{O}_{5}\left(\mathrm{Ta}_{2} \mathrm{O}_{5}: \mathrm{Tm}\right)$ thin films using co-sputtering of three $\mathrm{Tm}_{2} \mathrm{O}_{3}$ pellets and a $\mathrm{Ta}_{2} \mathrm{O}_{5}$ disc, and we obtained a remarkable PL peak around a wavelength of $800 \mathrm{~nm}$ due to the ${ }^{3} \mathrm{H}_{4} \rightarrow{ }^{3} \mathrm{H}_{6}$ transition of $\mathrm{Tm}^{3+}$ from a $\mathrm{Ta}_{2} \mathrm{O}_{5}: \mathrm{Tm}$ co-sputtered film after annealing at $900^{\circ} \mathrm{C}$ for $20 \mathrm{~min}$ [17].

In this study, we prepared $\mathrm{Ta}_{2} \mathrm{O}_{5}$ : Tm co-sputtered thin films using two $\mathrm{Tm}_{2} \mathrm{O}_{3}$ pellets, and we observed not only PL peaks around a wavelength of $800 \mathrm{~nm}$ but also violet PL peaks from the films after annealing for the first time.

\section{Experimental}

A $\mathrm{Ta}_{2} \mathrm{O}_{5}: \mathrm{Tm}$ thin film was deposited using a RF magnetron sputtering system (ULVAC, SH-350-SE). A schematic figure of the system was presented in our previous report [8]. A $\mathrm{Ta}_{2} \mathrm{O}_{5}$ disc $(99.99 \%$ purity, diameter 100 $\mathrm{mm})$ and two $\mathrm{Tm}_{2} \mathrm{O}_{3}$ pellets $(99.9 \%$ purity, diameter $20 \mathrm{~mm})$ were used as co-sputtering targets. The $\mathrm{Tm}_{2} \mathrm{O}_{3}$ pellets were placed on the $\mathrm{Ta}_{2} \mathrm{O}_{5}$ disc as shown in Figure 1. The flow rate of argon gas introduced into the vacuum chamber was $10 \mathrm{sccm}$, and the RF power supplied to the targets was $300 \mathrm{~W}$. A fused-silica plate $(1 \mathrm{~mm}$ thick) was used as a substrate, and it was not heated during co-sputtering.

We prepared four specimens from one as-deposited sample by cutting it using a diamond-wire saw, and we subsequently annealed the specimens in ambient air at $600^{\circ} \mathrm{C}, 700^{\circ} \mathrm{C}, 800^{\circ} \mathrm{C}$, or $900^{\circ} \mathrm{C}$ for 20 min using an electric furnace (Denken, KDF S-70). The annealing temperatures $\left(600^{\circ} \mathrm{C}-900^{\circ} \mathrm{C}\right)$ and the annealing time $(20 \mathrm{~min})$ are the same as those for our $\mathrm{Ta}_{2} \mathrm{O}_{5}: \mathrm{Tm}$ thin films reported in [17].

The PL spectra of the annealed specimens were measured using a dual-grating monochromator (Roper Scientific, SpectraPro 2150i) and a CCD detector (Roper Scientific, Pixis:100B, electrically cooled to $-80^{\circ} \mathrm{C}$ ) under excitation with a He-Cd laser (Kimmon, IK3251R-F, wavelength $\lambda=325 \mathrm{~nm}$ ).

\section{Results and Discussion}

Figure 2 presents PL spectra from the four specimens annealed at $600^{\circ} \mathrm{C}, 700^{\circ} \mathrm{C}, 800^{\circ} \mathrm{C}$, or $900^{\circ} \mathrm{C}$ for $20 \mathrm{~min}$. The 800-nm-peaks due to the ${ }^{3} \mathrm{H}_{4} \rightarrow{ }^{3} \mathrm{H}_{6}$ transition of $\mathrm{Tm}^{3+}$ were observed from all the specimens though the similar peak was so far observed only from our $\mathrm{Ta}_{2} \mathrm{O}_{5}: \mathrm{Tm}$ co-sputtered film prepared using three $\mathrm{Tm}_{2} \mathrm{O}_{3}$ pellets and annealed at $900^{\circ} \mathrm{C}$ [17]. The 800 -nm-peak intensities from the specimens annealed at $600^{\circ} \mathrm{C}$ and $900^{\circ} \mathrm{C}$ were much stronger than the specimens annealed at $700^{\circ} \mathrm{C}$ and $800^{\circ} \mathrm{C}$, and the maximum intensity was obtained from

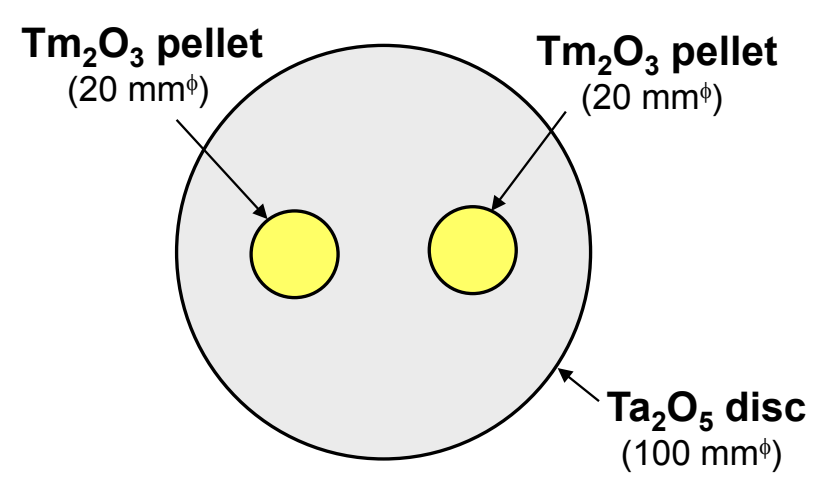

Figure 1. Schematic diagram of the sputtering target for cosputtering of two $\mathrm{Tm}_{2} \mathrm{O}_{3}$ pellets and a $\mathrm{Ta}_{2} \mathrm{O}_{5}$ disc. 


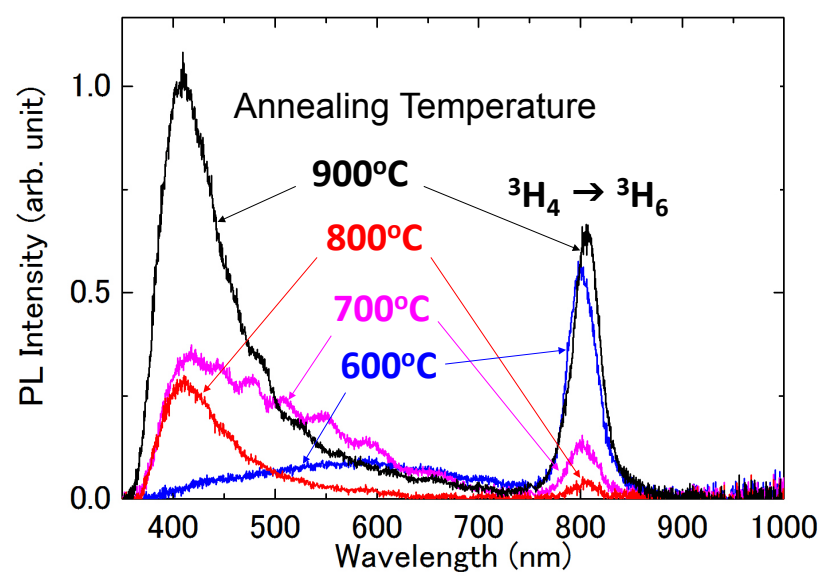

Figure 2. PL spectra of $\mathrm{Ta}_{2} \mathrm{O}_{5}: \mathrm{Tm}$ co-sputtered thin films annealed at $600^{\circ} \mathrm{C}, 700^{\circ} \mathrm{C}, 800^{\circ} \mathrm{C}$, or $900^{\circ} \mathrm{C}$ for $20 \mathrm{~min}$.

the specimen annealed at $900^{\circ} \mathrm{C}$. Broad PL spectra ranging from 400 to $750 \mathrm{~nm}$ were also observed from the specimens annealed at lower temperatures of $600^{\circ} \mathrm{C}$ and $700^{\circ} \mathrm{C}$. The broad spectra seem to originate from the ${ }^{1} \mathrm{G}_{4} \rightarrow{ }^{3} \mathrm{H}_{6}$ transition of $\mathrm{Tm}^{3+}[18]$ and/or oxygen-vacancy trap levels of $\mathrm{Ta}_{2} \mathrm{O}_{5}$ reported in [19].

On the other hand, comparatively narrow PL peaks around a wavelength of $400 \mathrm{~nm}$ (violet) were observed from the specimens annealed at higher temperatures of $800^{\circ} \mathrm{C}$ and $900^{\circ} \mathrm{C}$. We thus observed violet-light emission bands from our $\mathrm{Ta}_{2} \mathrm{O}_{5}$ :Tm co-sputtered thin films for the first time. The peak intensity from the specimen annealed at $900^{\circ} \mathrm{C}$ was approximately four-times stronger than that from the specimen annealed at $800^{\circ} \mathrm{C}$. The origin of the 400 -nm peaks seems to be the same as our non-doped $\mathrm{Ta}_{2} \mathrm{O}_{5}$ thin films deposited using RF sputtering because we observed PL peaks around wavelengths of $400-430 \mathrm{~nm}$ from $\mathrm{Ta}_{2} \mathrm{O}_{5}$ films annealed at $500^{\circ} \mathrm{C}$ or $600^{\circ} \mathrm{C}[5]$.

We previously reported that the $\delta-\mathrm{Ta}_{2} \mathrm{O}_{5}$ (hexagonal) phase in a $\mathrm{Ta}_{2} \mathrm{O}_{5}: \mathrm{Tm}$ thin film is very important for obtaining a strong PL peak at the wavelength of $800 \mathrm{~nm}$ from the film [17]. Therefore, the crystallizabilities of our $\mathrm{Ta}_{2} \mathrm{O}_{5}: \mathrm{Tm}$ thin films seem to be very important to obtain such violet PL peaks. We will conduct X-ray diffraction (XRD) measurements of the films in order to determine the relationship between the violet PL intensity and the crystallizability, and we will try to make the origin of the violet PL clear.

Such a $\mathrm{Ta}_{2} \mathrm{O}_{5}$ :Tm co-sputtered thin film seems to be used as a multi-functional coating film having both antireflection [3] and down-conversion [20]-[22] effects for realizing a high-efficiency silicon solar cell.

\section{Summary}

We prepared $\mathrm{Ta}_{2} \mathrm{O}_{5}$ :Tm thin films using co-sputtering of two $\mathrm{Tm}_{2} \mathrm{O}_{3}$ pellets and a $\mathrm{Ta}_{2} \mathrm{O}_{5}$ disc, and we observed not only PL peaks around a wavelength of $800 \mathrm{~nm}$ due to the ${ }^{3} \mathrm{H}_{4} \rightarrow{ }^{3} \mathrm{H}_{6}$ transition of $\mathrm{Tm}^{3+}$ but also violet PL peaks from the films after annealing for the first time. Comparatively narrow PL peaks around a wavelength of $400 \mathrm{~nm}$ were observed from the films annealed at $800^{\circ} \mathrm{C}$ and $900^{\circ} \mathrm{C}$ for $20 \mathrm{~min}$. The peak intensity from the film annealed at $900^{\circ} \mathrm{C}$ was approximately four-times stronger than that from the film annealed at $800^{\circ} \mathrm{C}$. The origin of the 400-nm peaks seems to be the same as our non-doped $\mathrm{Ta}_{2} \mathrm{O}_{5}$ thin films deposited using RF sputtering because we observe PL peaks around wavelengths of $400-430 \mathrm{~nm}$ from the $\mathrm{Ta}_{2} \mathrm{O}_{5}$ films. We will conduct XRD measurements of the $\mathrm{Ta}_{2} \mathrm{O}_{5}: \mathrm{Tm}$ thin films in order to determine the relationship between the violet PL intensities and the crystallizabilities of the films, and we will try to make the origin of the violet PL clear. Such $\mathrm{Ta}_{2} \mathrm{O}_{5}: \mathrm{Tm}$ co-sputtered thin films seem to be used as multi-functional coating films having both anti-reflection and downconversion effects for realizing high-efficiency silicon solar cells.

\section{Acknowledgements}

Part of this work was supported by JSPS KAKENHI Grant Number 26390073; and the "Element Innovation" Project by Ministry of Education, Culture, Sports, Science and Technology in Japan. Part of this work was conducted at the Human Resources Cultivation Center (HRCC), Gunma University, Japan. 


\section{References}

[1] Hanaizumi, O., Miura, K., Saito, M., Sato, T., Kawakami, S., Kuramochi, E. and Oku, S. (2000) Frontiers Related with Automatic Shaping of Photonic Crystals. IEICE Transactions on Electronics, E83-C, 912-919.

[2] Sato, T., Miura, K., Ishino, N., Ohtera, Y., Tamamura, T. and Kawakami, S. (2002) Photonic Crystals for the Visible Range Fabricated by Autocloning Technique and Their Application. Optical and Quantum Electronics, 34, 63-70. http://dx.doi.org/10.1023/A:1013382711983

[3] Cid, M., Stem, N., Brunetti, C., Beloto, A.F. and Ramos, C.A.S. (1998) Improvements in Anti-Reflection Coatings for High-Efficiency Silicon Solar Cells. Surface and Coatings Technology, 106, 117-120. http://dx.doi.org/10.1016/S0257-8972(98)00499-X

[4] Zhu, M., Zhang, Z. and Miao, W. (2006) Intense Photoluminescence from Amorphous Tantalum Oxide Films. Applied Physics Letters, 89, Article ID: 021915. http://dx.doi.org/10.1063/1.2219991

[5] Miura, K., Miyazaki, H. and Hanaizumi, O. (2008) Observation of Blue-Light Emission from Tantalum Oxide Films Deposited by Radio-Frequency Magnetron Sputtering. IEICE Transactions on Electronics, E91-C, 1669-1672.

[6] Sanada, T., Wakai, Y., Nakashita, H., Matsumoto, T., Yogi, C., Ikeda, S., Wada, N. and Kojima, K. (2010) Preparation of $\mathrm{Eu}^{3+}$-Doped $\mathrm{Ta}_{2} \mathrm{O}_{5}$ Phosphor Particles by Sol-Gel Method. Optical Materials, 33, 164-169. http://dx.doi.org/10.1016/j.optmat.2010.08.018

[7] Singh, M.K., Fusegi, G., Kano, K., Bange, J.P., Miura, K. and Hanaizumi, O. (2009) Intense Photoluminescence from Erbium-Doped Tantalum Oxide Thin Films Deposited by Sputtering. IEICE Electronics Express, 6, 1676-1682.

[8] Bange, J.P., Singh, M.K., Kano, K., Miura, K. and Hanaizumi, O. (2011) Structural Analysis of RF Sputtered Er Doped $\mathrm{Ta}_{2} \mathrm{O}_{5}$ Films. Key Engineering Materials, 459, 32-37. http://dx.doi.org/10.4028/www.scientific.net/KEM.459.32

[9] Singh, M.K., Miura, K., Fusegi, G., Kano, K. and Hanaizumi, O. (2013) Visible-Light Emission Properties of Erbium-Doped Tantalum-Oxide Films Produced by Co-Sputtering. Key Engineering Materials, 534, 154-157. http://dx.doi.org/10.4028/www.scientific.net/KEM.534.154

[10] Miura, K., Arai, Y., Osawa, T. and Hanaizumi, O. (2012) Light-Emission Properties of Europium-Doped TantalumOxide Thin Films Deposited by Radio-Frequency Magnetron Sputtering. Journal of Light \& Visual Environment, 36, 64-67.

[11] Miura, K., Osawa, T., Yokota, Y. and Hanaizumi, O. (2014) Fabrication and Evaluation of $\mathrm{Ta}_{2} \mathrm{O}_{5}: \mathrm{Y}_{2} \mathrm{O}_{3} \mathrm{Co}_{-} \mathrm{Sputtered}$ Thin Films. Results in Physics, 4, 185-186. http://dx.doi.org/10.1016/j.rinp.2014.09.004

[12] Miura, K., Kano, K., Arai, Y. and Hanaizumi, O. (2015) Preparation of Light-Emitting Ytterbium-Doped Tantalum-Oxide Thin Films Using a Simple Co-Sputtering Method. Materials Sciences and Applications, 6, 209-213. http://dx.doi.org/10.4236/msa.2015.62024

[13] Miura, K., Osawa, T., Suzuki, T., Yokota, Y. and Hanaizumi, O. (2015) Yellow Light Emission from Ta $\mathrm{O}_{5}: \mathrm{Er}_{\text {, }} \mathrm{Eu}, \mathrm{Ce}$ Thin Films Deposited Using a Simple Co-Sputtering Method. Results in Physics, 5, 26-27. http://dx.doi.org/10.1016/j.rinp.2014.11.003

[14] Miura, K., Osawa, T., Yokota, Y., Suzuki, T. and Hanaizumi, O. (2015) Photoluminescence Properties of Thulium and Cerium Co-Doped Tantalum-Oxide Films Prepared by Radio-Frequency Co-Sputtering. Materials Sciences and Applications, 6, 263-268. http://dx.doi.org/10.4236/msa.2015.64031

[15] Miura, K., Osawa, T., Suzuki, T., Yokota, Y. and Hanaizumi, O. (2015) Fabrication and Evaluation of Green-Light Emitting $\mathrm{Ta}_{2} \mathrm{O}_{5}$ :Er, Ce Co-Sputtered Thin Films. Results in Physics, 5, 78-79. http://dx.doi.org/10.1016/j.rinp.2015.02.002

[16] Miura, K., Arai, Y., Kano, K. and Hanaizumi, O. (2015) Fabrication of Erbium and Ytterbium Co-Doped TantalumOxide Thin Films Using Radio-Frequency Co-Sputtering. Materials Sciences and Applications, 6, 343-347. http://dx.doi.org/10.4236/msa.2015.65039

[17] Miura, K., Osawa, T., Yokota, Y., Suzuki, T. and Hanaizumi, O. (2014) Fabrication of Tm-Doped Ta $2 \mathrm{O}_{5} \mathrm{Thin}_{\text {Films }}$ Using a Co-Sputtering Method. Results in Physics, 4, 148-149. http://dx.doi.org/10.1016/j.rinp.2014.08.011

[18] Macatrao, M., Peres, M., Rubinger, C.P.L., Soares, M.J., Costa, L.C., Costa, F.M., Monteiro, T., Franco, N., Alves, E., Saggioro, B.Z., Andreeta, M.R.B. and Hernandes, A.C. (2009) Structural and Optical Properties on Thulium-Doped LHPG-Grown $\mathrm{Ta}_{2} \mathrm{O}_{5}$ Fibres. Microelectronics Journal, 40, 309-312. http://dx.doi.org/10.1016/j.mejo.2008.07.033

[19] Devan, R.S., Lin, C.-L., Lin, J.-H., Wen, T.-K., Patil, R.A. and Ma, Y.-R. (2013) Effective Photoluminescence in a Large-Area Array of $\mathrm{Ta}_{2} \mathrm{O}_{5}$ Nanodots. Journal of Nanoscience and Nanotechnology, 13, 1001-1005. http://dx.doi.org/10.1166/jnn.2013.6088

[20] Rodriguez, V.D., Tikhomirov, V.K., Mendez-Ramos, J., Yanes, A.C. and Moshchalkov, V.V. (2010) Towards Broad Range and Highly Efficient Down-Conversion of Solar Spectrum by $\mathrm{Er}^{3+}-\mathrm{Yb}^{3+}$ Co-Doped Nano-Structured Glass- 
Ceramics. Solar Energy Materials and Solar Cells, 94, 1612-1617. http://dx.doi.org/10.1016/j.solmat.2010.04.081

[21] Aarts, L., van der Ende, B.M. and Meijerink, A. (2009) Down Conversion for Solar Cells in NaYF 4 :Er, Yb. Journal of Applied Physics, 106, Article ID: 023522. http://dx.doi.org/10.1063/1.3177257

[22] Ueda, J. and Tanabe, S. (2011) Broadband near Ultra Violet Sensitization of $1 \mu \mathrm{m}$ Luminescence in $\mathrm{Yb}^{3+}-\mathrm{Doped} \mathrm{CeO}_{2}$ Crystal. Journal of Applied Physics, 110, Article ID: 073104. http://dx.doi.org/10.1063/1.3642984 